\title{
Teacher's Perception of Using ESA Elements in Boosting Speaking Ability of EFL Learners: A Task-based Approach
}

\author{
Hooshang Khoshsima \\ Faculty of Management and Humanities, Chabahar Maritime University, Chabahar, Iran \\ Hadi Shokri \\ Faculty of Management and Humanities, Chabahar Maritime University, Chabahar, Iran
}

\begin{abstract}
There has always been tremendous studies regarding teachers' perception of using a definite approach in boosting speaking ability of EFL learners; however, fewer studies have stressed the essentiality of student engagement through Harmer's ESA elements involved in enhancing speaking performance of EFL learners. The aim of the present study is to put an effort into investigating teachers' perception of teachinglearning techniques through the utilization of three engage, study and activates (ESA) elements involved in teaching of tasks in mastering Iranian intermediate EFL learners' speaking skills. Based on this notion, a number of $10 \mathrm{EFL}$ experienced teachers were enrolled in conduction of the study. In order to analyze teachers' apprehension of ESA elements, a questionnaire which contained a five- point 37 Likert-type close-ended items was utilized. The results of the teachers' questionnaire revealed that most of the teachers hold a positive perception of implementing ESA elements in their classroom settings as an instructional approach in boosting speaking ability of EFL learners. In conclusion, findings of the study approve implementation of ESA in classroom setting. It is expected that the implications of the study may significantly contribute to the work of EFL teachers, EFL learners, syllabus designers, supervisors, material producers, textbook writers and researchers.
\end{abstract}

Index Terms —ESA elements, teachers' perception, speaking ability

\section{INTRODUCTION}

As a matter of fact, mastering speaking ability has always been of a great concern to most EFL learners taking part in international English language tests. Subsequently, implementing the best course of action which significantly boosts EFL learner's oral abilities has also been a controversial issue for TEFL teachers.

Regarding speaking and its importance, Ur, P (1991) considers speaking as the most essential skill. He notes that among the four skills of listening, speaking, reading and writing, speaking gains significant importance. He also maintains that those who grasp knowledge of a language are said to be the 'speakers' of that language, as though speaking contains all other types of knowledge and to a larger extent most EFL learners tend to learn speaking. Rivers (1981) argues that the use of speaking in L2 situations is twice as much as other skill like reading and writing in daily communications (Cited in Torky, 2006). Correspondingly, Richards and Renandya (2002) consent on the fact that most EFL learners take English courses so as to expatiate their proficiency in oral abilities. Harmer (2007) clearly stresses on the communicative dimention and language use in L2 settings. He also encapsulates that adequate input and learner engagement in tasks and topics would significantly affect learner's oral abilities. Additionally, he claims that if learners activate their cognitive abilities and consider their minds and hearts, they will understand and learn substantial materials considerably.

In accordance with the abovementioned statements, it seems essential to say that speaking is the means through which learners can communicate with others specifically for the purpose of achieving certain goals, putting their ideas across or expressing their emotions, feelings, viewpoints and so on. Likewise, however, there is a consensus that speaking is the most frequently used skill in most settings.

Prince (2004 as cited in Timothy T. Diemer and et al) holds that student engagement is closely associated with positive learning outcomes. Likewise, Kinzi (2010 as cited in Timothy T. Diemer and et al) describes the association between student engagement and academic success as follow:

A substantial body of research indicates that once students commence studying at a college or university a key factor as to whether they will put considerable amount of effort and strive to partake in educationally meaningful activities is essentially dependent upon the extent to which they are engaged in academically well-structured environments. Quite simply, to make certain how many students graduate and make the most of their undergraduate and postgraduate education, universities need to first assure the learning environment offer prolific and educationally purposeful opportunities and subsequently concentrate squarely on promoting student engagement. 
Although there have been tremendous studies on the essentiality of teaching and enhancing speaking ability of EFL learners, the problems and inadequacies are not alleviated yet. Correspondingly, most of the works on teaching speaking through tasks proved to have their own weaknesses, merits and demerits. And most of these weaknesses can be attributed to their ignorance of learner engagement, learner interest and learner activation. Correspondingly, considering the abovementioned barriers which may hinder learners attempt to enhance their speaking ability, this study put an effort into filling the gap in the field of language teaching and learning. Therefore, the present study is significant owing to the grounds that it tries to remove the shortcomings of former studies by investigating teachers' apprehension of implementing Harmer's ESA (Engagement, Study, and Activate) elements utilizing a Task-based syllabus in boosting speaking ability of EFL learners.

This study also aims to assess and identify teachers' perception of utilizing this approach on improving speaking ability of EFL learners. Therefore, it tries to explore teachers' understanding and knowledge regarding the relevance of using ESA approach for better language teaching and learning. To do this, the present study attempts to give some suggestions for teachers to stimulate student's speaking performance and overcome the difficulties they have to encounter with in teaching speaking English for Iranian EFL learners.

\section{LITERATURE REVIEW}

\section{A. Speaking Nature's Language}

Bygate (1987) maintains that speaking in a second language (L2) involves the improvement of a specific kind of communicative skill. Additionally, he states that since oral language involves production circumstances, it contradicts from written language in its ordinary grammatical, lexical and discourse patterns. The differences between these two are discussed on the discussion of the nature of speaking. Moreover, some of the processing skills required in speaking vary from those involved in reading and writing. Additionally, on the discussion of the nature of spoken language, Nunan (1989) distinguishes spoken language from written language. He summarizes the differences as follow:

\section{Spoken language}

Context dependent

Dialogic in nature

Records the world as happens

(P.26).

He also differentiates between two basic language functions, i.e. the transactional and the interactional talk. The former is produced in order to get things done. And the latter is produced for social purposes. According to Nunan (1989, P.32) successful oral communication involves:

1. the ability to articulate phonological features of the language comprehensibly

2. command of stress, rhythm, intonation patterns

3. an acceptable degree of fluency

4. transactional and interpersonal skills

5. skills in negotiating meaning

6. skills in taking long and short turns

Additionally, he holds that teachers can apply both the bottom-up and the top-down approaches to teaching speaking in their classes. He defines the bottom-up approach to teaching speaking as follow: The students commence with the smallest units of language, i.e. individual sounds, and continue with the mastery of words and sentences to discourse. The top-down view, on the other hand, advocates that the students commence with the larger chunks of language, which are embraced in authentic contexts, and use their knowledge of the contexts to understand and use the smaller language elements accurately.

\section{B. Classroom Interaction and Student Engagement}

For EFL learners, experiencing real communicative situations in which they can assert themselves get their message crossed or expressing their opinions with regard to fluency and accuracy is crucially important. Hence, applying an educational strategy which can enhance their learning plays an important role in their learning process. Having this in mind, it should go without saying that the concept of classroom interaction which emphasizes teacher-learner, learnerlearner interaction, negotiation of meaning and feedback worth considering. Supporting the abovementioned claims, Hughes (1994) believes that one of the major objectives of teaching spoken language to EFL learners is to master their ability in interacting successfully in the target language which involves both comprehension and production. (Cited in Silva, 2012)

In their pioneering study of teacher-learner interaction, Sinclair and Brazil (1982) claimed that learners 'have only very restricted opportunities to participate in the language of the classroom'. In similar vein, Nunan (1987) concluded that 'there is increasing proof that, in communicative classroom settings, interactions may, in particular, not be very communicative after all' (p.144). The growing evidence Nunan adduces includes studies that characterize teacherlearner interaction as being almost entirely teacher-led and dominated, and as consisting largely of IRF (initiateresponse-follow up) sequences, of which the initiating element is almost always a display question (as opposed to a referential one). Elsewhere, Sinclair and coulthard (1975 as cited in Ur, P. 1991) believe that the most decent kind of 
classroom interaction is generally known as 'IRF' - Initiation- Response- Feedback: in this type of interaction the teacher launches an exchange, typically in the form of a question, and one of the learners answers, the sequence goes on.

A positive gloss of this extract would highlight the scaffolding of instruction that the teacher provides through her questions, and the way in which learners are actively involved in achieving an instructional goal. (Thornbury, S 1996a, as cited in Trappes-Lomax and Gibson Ferguson 2002).

Student engagement is a new and ongoing field of study and the finding are very challenging. Shulman (2002) stress the essentiality of student engagement and say "learning begins with student engagement" (p.37).

In any learning situation, especially in classroom setting, any achievement without considering student engagement would lead to incomplete conclusions or results.

The research literature elaborates upon Newmann and Colleagues (1999) (as cited in Aardema, Thomas P, 2013) definition by dividing student engagement into three levels: behavioral engagement, emotional engagement and cognitive engagement.

The focus of behavioral engagement is mainly on the tenet of participation and involvement of learners in social as well as academic activities essential for achieving positive outcomes. Emotional engagement refers to the learner's reaction toward the teacher, classmate and the academic course. Learners participating in class show positive and sometimes negative attitude or reaction. These emotions include: boredom, happiness, interest, anxiety, stress, etc. Cognitive engagement is the amount of time, effort, willingness, thoughtfulness and strategies exerted or employed by learners necessary for comprehension of complex ideas in carrying out tasks.

\section{ESA Approach as an Instructional TEFL Methodology}

Over the last decade, ELT teachers have made use of PPP model of Presentation, Practice and production as their desired model of teaching. This model of teaching proved to be effective; however, it proved to have many disadvantageous. One of the salient cons of implementing this model is that it falls short in communicative classes. This is due to the fact that it does not work well when learners are asked to produce complex language problems at the discourse level. Another short coming of this model can be attributed to the amount of teacher talking time which is disproportionately high compared to that of the learner talking time. This is mainly in the presentation phase of the PPP model. Another demerit of this model arises from its principles is its overemphasis on accuracy over fluency when the focus is on language use rather than usage. Finally, the said model does not allow for recap, that is, movement within different stages. Now, it can convincingly be argued that ESA approach can be preferred.

In response to the shortcomings directed toward PPP model, Harmer proposed a more effective and practical alternative model of teaching. Harmer (2007) different trilogy of teaching elements which he calls as a principled eclecticism is referred as ESA: Engage Study, and Activate.

- E stands for Engage. The principal aim of engagement phase requires teachers to arouse learner's curiosity, involvement, attention, emotion and interests. In this phase, teachers can make use of games, interesting anecdotes, storytelling, recordings, picture descriptions etc. According to the said propositions Harmers (2007) state that "unless students are emotionally engaged with what is going on, their learning will be less effective" (p.66).

- $\mathrm{S}$ which stands for Study bases its main principal on language usage. The tasks at this phase center around forms of the language and the information about the construction of how it is formed. This phase entails focus on learner-led grammar discovery, eliciting grammar from learners rather than teacher-led presentations. The activities of this phase grow out of communicative tasks where learners focus on forms is drawn from the teacher-led discussions or through their own noticing activities. Activities of this type range from relative clauses, specific intonation patterns to collocation of a particular word or the way a lexical phrase is made or used. Harmer believes that successful language learning is heavily grounded on a sensible integration of subconscious acquisition of language.

- Finally, A which stands for Activate is the stage at which learners are engaged in more communicative and meaning-focused tasks. These tasks require learners to use the language communicatively and as free as the can. Fluency is more emphasized and learners focus is on the free use of the language rather than accuracy.

\section{Task}

Ur, P (1991) defines task as essentially goal-oriented activity which requires the group or pair, to regain the goal which is normally expressed by an observable result. These include a drawing, a rearrangement of jumbled items, a spoken summary and brief notes or lists. This result should be achieved by interaction among participants; therefore the instruction involved in teaching tasks should 'reach a consensus' or 'find out every one's opinion' In performing these types of activities, he believes that task -centered activities invokes more talk, more even participation, more motivation and enjoyment.

\section{E. Task Components, Task Types, Task Variables and Features}

When deciding to use or design any kind of task in the classroom, the first thing that comes to the mind is which components of the task are better to be used or chosen in order to get better outcomes. Or which type of the task most suits to the classroom setting. As an example, deciding which type of task is beneficial for communication. Also, there are some task variables that display the characteristics of a good task. Ellis (2000) in his book 'Task-based research and language pedagogy' composes that instructional information about consequential task variables procured through 
research can aid teachers in determining what tasks to practice and what time (as cited in Ellis 2005). As a whole, implications derived from task components, task types and task variables provide useful insights for teachers and language trainers to make the process of language teaching and learning effective (Edwards and Willis 2005).

Candlin (1987) endorses that input, roles, setting, actions, monitoring, outcomes and feedback are the constituent of a task. He defines input as the data presented for learners to work on. Roles define the association between participants in a task. Setting refers to the classroom and out-of-class arrangements included in the task. Actions are the strategies and sub-tasks that the learners perform. Monitoring refers to the observation of the progressive task. Outcomes refer to the objectives of the task, and feedback refers to the assessment of the task.

According to Shavelson and Stern (1981) in designing a task, the following elements should be taken into consideration:

- Content - the theme, topic and subject matter to be instructed

- Materials - the concrete things or materials that students are able to observe/manipulate

- Activities - the things the students and teacher will be performing during the instruction

- Goals - the teachers' overall objective for the task

- Students - their capabilities, requirements and enthusiasms are essential

- Social community - the whole class and its perception of 'groupness'.

(P. 478).

Nunan (1999) states that there are four components in defining a language learning task: the goals, the input, the activities taken from the input and eventually the roles of the teacher and learners.

Goals: Nunan refers to goals as the vague general intentions behind any given learning task. Goals yield a point of proximity between the task and the broader curriculum. For example goals may answer some communicative questions like 'Why did you get learners involved in the communicative task?' the possible answers to this question might be"

'I wanted to boost their speaking ability.'

'I wanted to encourage them to get engaged in the negotiation of information.'

'I wanted them to master their interactional skills'

Input: He refers to input as the data that form the point of departure for the task. Inputs can be taken from a wide range of sources. For instance, Hover (1986) derives the input for communicative tasks from different sources. These are newspaper extracts, picture stories, business cards, family trees, recipe, weather forecast, note to a friend, curriculum vitae, etc.

Activities: refer to the actual work that learners carry out with the input which shapes the withdrawal of the learning task. Clark and Silberstein (1977) maintain that the activities performed in the classroom setting must be the same as the real world as closely as possible. Correspondingly, thanks to the fact that language is a means to communication, methods and materials must also focus on the message, not the medium. Consequently, findings of research into the study of tasks may provide teachers with intuitions that enable them to make language teaching more beneficial.

Argumentatively, it can be put forward that tasks types can be recognized in a number of ways. For example, Nunan (1989) offers two inclusive categories: real-world tasks like using telephone and pedagogic tasks like problem solving. These can be further be subcategorized into other classifications, by means of language function like giving instructions, apologizing, making suggestions, or by means of cognitive processes or knowledge hierarchies such as listing, ordering and sorting, problem solving, being creative. Correspondingly, others may categorize tasks by topic, by the language skills needed for completion, or by whether the result is closed or open which is sometimes called divergent and convergent tasks (Long, 1989). Pica, Kanagy and Falodun (1993) take as their starting point the kind of interaction that takes place during task completion, e.g. one-way or two-way information flow, leading to five kinds: jigsaw tasks, information gaps, problem-solving, decision-making and opinion exchange. Making a distinction among different task types seems paramount, as it allows researchers to explore which types most considerably enhance learning (as cited in Edwards, C \&. Willis, J. 2005, p.19).

In addition to task types, task variables also provide useful insight into better understanding of the process of taskbased language teaching. Edwards, C and Willis, J (2005) provide some examples of tasks variables. These include task characteristics such as whether the task is structured by providing some courses of induction into managing the interaction, therefore aiding task completion, cognitive difficulty and familiarity of the task involving the amount of antecedent rehearsal of the task-type or recapitulation of the same or similar tasks. The criteria under which tasks are carried out can also be regulated. Interlocutor familiarity with the time arrangement, performance preconditions such as public or private, and whether the interlocutor is a native or non-native speaker are all instances of task variables (p.20).

Most of the tasks used in classrooms are prescribed by official course syllable or course books and allow little opportunities for teachers to provide learners with new type of activities. Most of these tasks introduced by course books or official course syllables lack the features of being interesting, novel, having real life characteristics, etc.

Dornyei, Z (2001, Pp. 76-77) lists some ideas about the most motivating features of task content. He believes that a task must belhave:

- Challenging. That is to say, most they must challenge learners by performing some computer games; crossword or puzzles which activates learners sense of completion, problem solving and discovery abilities. 
- Have interesting content: tasks which connect the topic with learners' real life experiences or the things learners already find interesting.

- Novel: the tasks which have some novelty would bring variety and also would eliminate the factor of being monotonous.

- Fantasy: tasks which arouse leaners imagination or fantasy will engage learners. For example, by making makebelieve story, pretend plays or act out.

- Personal: learners inherently like the topics or tasks which they relate the content to their own lives.

- Competition: The opportunity to challenge can add arousal and excitement to learning tasks, irrespective of whether the challenge is for reward (e.g. a packet of candies) or simply for the satisfaction of winning.

- Humor: 'Humor is many things and one of them is interesting'

\section{Methodology}

\section{Date Collection Instruments}

The research instruments used in this study included questionnaires for teachers and teacher observation.

\section{Teacher's Questionnaire}

The questionnaire was adapted from Karavas-Doukas (1996) and Kim (1999) cited in Beyen (2008) composed a fivepoint 37 Likert-type close-ended items. The information which was embodied in the questionnaire aimed to find out the teachers understanding and perception of teaching speaking through application of ESA approach on tasks. The questionnaire for teachers encompassed the primary principles of ESA approach (i.e. aspects of conceptual perspective, students learning perspective, perspective on instructional activities, the role of the teacher and the role and contribution of students).

The questionnaire included a total of 37 items. In section one 21 items, which were designed to identify teachers' understandings of ESA concepts and their views on ESA classroom implementation, were given numerical scores (e.g. „Strongly Agree" $=5$; „Agree" $=4$; „Undecided" $=3$; „Disagree" $=2$ and „Strongly Disagree" $=1$ ). Similarly, in section two items (22-37) which were set out to identify teachers" frequency of practice of the communicative language teaching principles with the statements on five-point Likert scales ranging from 5 specifying "always", 4 specifying "usually",3 specifying "sometimes", 2 specifying " rarely" and 1 specifying "never".

\section{Validity and Reliability of the Questionnaire}

Before the commencement of the existent data collection process, the questionnaire was put forward essentially to meet the aims of the study, and the items were adapted from Karavas-Doukas (1996) and Kim (1999) cited in Beyen (2008). The adapted questionnaire was given to two TEFL instructors in Chabahar Maritime University to evaluate the items analytically in terms of content validity, face validity, comprehensibility of the items and if they fit to measure the objectives of the study. Consequently, in order to check the internal consistency of the questionnaire results, a pilot study on teachers' questionnaire was conducted using $10 \mathrm{MA}$ students of teaching with more than 4 to 5 years of teaching experience. The pilot study on teachers' questionnaire was conducted in another school all chosen from Tehran language school with more than 5 years of experience in teaching since the MA students were involved in the actual study. The participants involved in the pilot study were not included in the sample during the administration of the final form of the questionnaire.

The reliability of the test instrument was tested by Cronbach alpha method. The calculated Cronbach alpha of the test instruments were 0.82 and 0.85 for the perception and practice items. Thus, the instruments were found to be reliable to collect data for the main study.

\section{Classroom Observation}

The classroom observation was carried out in order to see whether teachers and students practiced the principles of ESA approach (besides what they responded to questionnaires) in EFL classroom while the actual class lesson was going on. In order to meet the objectives of the observation, a speaking observation was developed and employed. This instrument was submitted to the panel of jury to determine its validity and appropriateness of the skills needed to be applied in the classroom setting. The observation was made based on checklists which focused on classroom instructional activities or techniques employed by teachers, the role teachers and learners played and instructional materials used in the teaching learning process. Based on the objectives of the study, which was to ensure whether teachers approved the application of ESA approach on task in teaching speaking or not, this observation checklist was provided. The main aim of this checklist is to familiarize the teachers with the principles of Harmers ESA approach in order to get ready to answer the questions asked about their perception of using this approach. Therefore, it should be mentioned that the questionnaires the 10 teachers were given after the treatment in the experimental group were based on this observation checklist provided in advance. In this process 10 different M.A teaching candidates with nearly 4 or 5 years of experiences were asked to fill out the observation checklist. At the end of the treatment, the same teachers were asked to answer to the questionnaires asking about their perception of using this approach.

\section{PROCEDURES}


Conduction of the present study was an attempt to see whether teachers approve of using this type of instruction and the procedures used in collecting the data involve a number of steps taken by the researcher himself:

Since the questionnaires were based on the method being used in class and in order for the teachers to answer the questionnaire, First of all, it was important to get the teachers acquainted with the method being used in the classroom. Therefore, it was necessary to ask the teachers to participate in the classes and fill out the observation checklist. Hence, an observation checklist which was based on the tenets of the method being used was prepared in advance. Then, at the end of the term when the teachers had already based their perceptions according to the observation checklist, a questionnaire was given to teachers to analyze their perception of using the ESA approach in class. Teachers' perception questionnaire is carried out with the intention of arriving at possible conclusions which can lead to some beneficial recommendations regarding the best course of action in teaching methodology. The teachers' perception questionnaire contains six sections examining different perspectives. These include: conceptual perspective, students' learning perspective, perspective on instructional activities, perspective on teachers' role, perspective on learners' role and classroom practice. Therefore, the data analysis is approached separately in each section of the questionnaire. The data collected from the questionnaires were analyzed using a SPSS software. In this process, the results were shown by the mean, frequency and percentages each teacher answered to each question asked. Finally, the total mean scores of the teachers' responses were given as to the concluding remark of the study.

\section{RESULTS}

Findings of the Study

The data collection regarding each section of the questionnaire is demonstrated and analyzed using frequency, mean differences and percentage.

TABLE 1.

CONCEPTUAL PERSPECTIVES

\begin{tabular}{|c|c|c|c|c|c|c|c|c|c|c|c|c|}
\hline \multirow[t]{2}{*}{ No } & \multirow[t]{2}{*}{ Items } & \multicolumn{2}{|l|}{5} & \multicolumn{2}{|l|}{4} & \multicolumn{2}{|l|}{3} & \multicolumn{2}{|l|}{2} & \multicolumn{2}{|l|}{1} & \multirow[t]{2}{*}{ Mean } \\
\hline & & $\mathrm{F}$ & $\%$ & $\mathrm{f}$ & $\%$ & $\mathrm{f}$ & $\%$ & $\mathrm{~F}$ & $\%$ & $\mathrm{~F}$ & $\%$ & \\
\hline 1. & $\begin{array}{l}\text { Good EFL instruction is virtually synonymous with ESA } \\
\text { approach. }\end{array}$ & - & - & 5 & 50 & 4 & 40 & 1 & 10 & - & - & 3.40 \\
\hline 2. & $\begin{array}{l}\text { An ESA approach is the most progressive instructional } \\
\text { approach in the field of EFL. }\end{array}$ & 1 & 10 & 5 & 50 & 3 & 30 & 1 & 10 & - & - & 3.60 \\
\hline 3. & $\begin{array}{l}\text { The ESA approach gives equal attention to all language skills } \\
\text { rather than attention only to productive skills. }\end{array}$ & - & - & 2 & 20 & 3 & 30 & 5 & 50 & - & - & 2.70 \\
\hline 4. & $\begin{array}{l}\text { ESA help learners to take responsibility of their learning } \\
\text { process more than teacher centered approaches. }\end{array}$ & 1 & 10 & 4 & 40 & 5 & 50 & - & - & - & - & 3.60 \\
\hline 5. & $\begin{array}{l}\text { The ESA approach to language teaching encourages } \\
\text { responsibility and self-discipline and allows each student to } \\
\text { develop his/her full potential. }\end{array}$ & - & - & 4 & 40 & 4 & 40 & 2 & 20 & - & - & 3.20 \\
\hline $\begin{array}{l}\text { Total } \\
\text { mean }\end{array}$ & & & & & & & & & & & & 3.3 \\
\hline
\end{tabular}

Table1 shows the teachers' conceptual perspective and attitude regarding the use of ESA approach on tasks in mastering EFL learners speaking proficiency. According to the item1, findings of the conceptual perspective denote that approximately half of the teachers agreed that good EFL instruction is virtually synonymous with ESA approach. Likewise, nearly half of the teachers agreed that an ESA approach is the most progressive instructional approach in the field of EFL. However, teachers on item 3 reported their agreement on productive skills and over fifty percent of them claimed that ESA approach is less given attention to all other language skills.

In general, according to the total mean of the teachers' conceptual perspective which equal 3.3, it can clearly be said that about over half of the teachers have a very high opinion of the ESA approach.

TABLE 2.

STUDENTS' LEARNING PERSPECTIVES

\begin{tabular}{|c|c|c|c|c|c|c|c|c|c|c|c|c|}
\hline \multirow[t]{2}{*}{ No } & \multirow[t]{2}{*}{ Items } & \multicolumn{2}{|l|}{5} & \multicolumn{2}{|l|}{4} & \multicolumn{2}{|l|}{3} & \multicolumn{2}{|l|}{2} & \multicolumn{2}{|l|}{1} & \multirow[t]{2}{*}{ Mean } \\
\hline & & $\mathrm{f}$ & $\%$ & $\mathrm{f}$ & $\%$ & $\mathrm{~F}$ & $\%$ & $\mathrm{~F}$ & $\%$ & $\mathrm{~F}$ & $\%$ & \\
\hline 6. & $\begin{array}{l}\begin{array}{l}\text { Students" involvement is best promoted in ESA EFL } \\
\text { classroom. }\end{array} \\
\end{array}$ & 7 & 70 & 3 & 30 & - & - & - & - & - & - & 4.70 \\
\hline 7. & $\begin{array}{l}\text { Students" social development is best promoted in ESA EFL } \\
\text { classroom. }\end{array}$ & 3 & 30 & 6 & 60 & 1 & 10 & - & - & - & - & 4.20 \\
\hline 8. & $\begin{array}{l}\text { Students are more willing to take risk in ESA EFL classes than } \\
\text { teacher fronted (lockstep) classes. }\end{array}$ & 5 & 50 & 3 & 30 & 2 & 20 & - & - & - & - & 4.30 \\
\hline 9. & $\begin{array}{l}\text { The ESA approach to language teaching produces fluent } \\
\text { learners. }\end{array}$ & 4 & 40 & 4 & 40 & 2 & 20 & - & - & - & - & 4.20 \\
\hline $\begin{array}{l}\text { Total } \\
\text { mean }\end{array}$ & & & & & & & & & & & & 4.35 \\
\hline
\end{tabular}

As can be seen from the above table, clearly a great percentage of teachers (70\%) strongly agreed on the tenets of ESA student involvement. Similarly, the other 30 percent also voted in favor of the student engagement in ESA 
approach. Therefore, it can be assured that this type of instruction is the best method of engaging learners in class discussion. Most notably, in item 7, over 60 percent of respondents agreed that Students" social development is best promoted in ESA EFL classroom. In the same manner, most of the teachers (80\%) claimed that students are more risktakers in ESA classes. According to item 9, it should also be stated that ESA approach produces fluent learners. Eighty percent of the teachers reflected their agreement in this favor.

Generally speaking, it can be certainly argued that students' active learning is best promoted in ESA approach. The total mean of 4.35 indicated the high positive role of this type of instruction in teaching productive skills.

TABLE 3

PERSPECTIVE ON INSTRUCTIONAL ACTIVITIES

\begin{tabular}{|c|c|c|c|c|c|c|c|c|c|c|c|c|}
\hline \multirow[t]{2}{*}{ No } & \multirow[t]{2}{*}{ Items } & \multicolumn{2}{|l|}{5} & \multicolumn{2}{|l|}{4} & \multicolumn{2}{|l|}{3} & \multicolumn{2}{|l|}{2} & \multicolumn{2}{|l|}{1} & \multirow[t]{2}{*}{ Mean } \\
\hline & & $\mathrm{F}$ & $\%$ & $\mathrm{f}$ & $\%$ & $\mathrm{f}$ & $\%$ & $\mathrm{~F}$ & $\%$ & $\mathrm{~F}$ & $\%$ & \\
\hline 10. & $\begin{array}{l}\text { In EFL programs, content learning is best accomplished with an } \\
\text { ESA approach. }\end{array}$ & 3 & 30 & 5 & 50 & 2 & 20 & - & - & - & - & 4.10 \\
\hline 11. & $\begin{array}{l}\text { English speaking proficiency is more easily achieved in an ESA } \\
\text { class. }\end{array}$ & 4 & 40 & 4 & 40 & 2 & 20 & - & - & - & - & 4.20 \\
\hline 12. & Learning skills are best developed in an ESA EFL classroom. & 2 & 20 & 4 & 40 & 4 & 40 & - & - & - & - & 3.80 \\
\hline 13. & $\begin{array}{l}\text { In ESA, group work activities are essential in providing } \\
\text { opportunities for co-operative relationships to emerge and in } \\
\text { promoting genuine interaction among students. }\end{array}$ & 4 & 40 & 4 & 40 & 2 & 20 & - & - & - & - & 4.20 \\
\hline 14. & $\begin{array}{l}\text { In ESA, group work activities take too long to organize and } \\
\text { waste a lot of valuable teaching time. }\end{array}$ & 2 & 20 & 5 & 50 & 2 & 20 & - & - & 1 & 10 & 3.70 \\
\hline 15. & $\begin{array}{l}\text { Students do their best when taught as a whole class by their } \\
\text { teacher. }\end{array}$ & 2 & 20 & 5 & 50 & 3 & 30 & - & - & - & - & 3.90 \\
\hline $\begin{array}{l}\text { Total } \\
\text { mean }\end{array}$ & & & & & & & & - & - & - & - & 3.98 \\
\hline
\end{tabular}

Taking a quick look at the above table, it will be made clear that item 10 shows great a high percentage of teachers with a mean value of 4.20 agree on the terms of content learning and ESA approach. Similarly, with the mean of 4.20 the teachers also hold that speaking proficiency is best achieved in ESA approach. About 40 percent of the teachers agreed that learning skills are best developed in ESA classroom and likewise 40 percent of them were also undecided and the other 20 percent strongly affirmed that ESA classroom can develop learners learning skills. Regarding group work activities, about $80 \%$ of the respondents strongly affirmed that group work activities objectives are best achieved through ESA approach.

In general, the mean score of 3.98 is true measure that most EFL teachers hold a positive outlook of the principles of ESA approach instructional perspectives. As it could be seen ESA takes quite a large number of instructional principles into consideration and promote active learning through student engagement, focus on language forms and receiving feedback as to how many students have learned the materials being taught.

TABLE 4.

PERSPECTIVE ON TEACHER'S ROLE

\begin{tabular}{|c|c|c|c|c|c|c|c|c|c|c|c|c|}
\hline \multirow[t]{2}{*}{ No } & \multirow[t]{2}{*}{ Items } & \multicolumn{2}{|l|}{5} & \multicolumn{2}{|l|}{4} & \multicolumn{2}{|l|}{3} & \multicolumn{2}{|l|}{2} & \multicolumn{2}{|l|}{1} & \multirow[t]{2}{*}{ Mean } \\
\hline & & $\mathrm{f}$ & $\%$ & $\mathrm{f}$ & $\%$ & f & $\%$ & f & $\%$ & $\mathrm{~F}$ & $\%$ & \\
\hline 16. & Teachers play a facilitator role in ESA class. & 6 & 60 & 4 & 40 & - & - & - & - & - & - & 4.60 \\
\hline 17. & $\begin{array}{l}\text { The role of the teacher in the language classroom is to impart } \\
\text { (demonstrate) knowledge through activities such as } \\
\text { explanation, writing and giving examples. }\end{array}$ & 8 & 80 & 2 & 20 & - & - & - & - & - & - & 4.40 \\
\hline 18. & $\begin{array}{l}\text { The teacher should act as an independent participant within the } \\
\text { learning-teaching group }\end{array}$ & 4 & 40 & 4 & 40 & 2 & 20 & - & - & - & - & 4.20 \\
\hline 19. & $\begin{array}{l}\text { The teacher must supplement the textbook with other materials } \\
\text { and tasks so as to develop the student's communicative skill. }\end{array}$ & 5 & 50 & 4 & 40 & 1 & 10 & - & - & - & - & 4.40 \\
\hline $\begin{array}{l}\text { Total } \\
\text { mean }\end{array}$ & & & & & & & & & & & & 4.40 \\
\hline
\end{tabular}

With regard to table4, teachers with the mean of 4.60 confirmed the role of teachers in ESA as facilitator. Focusing on item 17 , most of the teachers $(80 \%)$ confirmed that the role of the teacher in the language classroom is to demonstrate knowledge through activities such as explanation; writing and giving examples. In the same manner, regarding item 18, the mean value of 4.40 affirms the teachers' role as an independent participant. At last, in item 19, teachers with the mean value of 4.40 voted in favor that the teacher must supplement the textbook with other materials and tasks so as to develop the student's communicative skill.

As the concluding remark of this section, it suffice to state that even though a small proportion of the teachers (30\%) were undecided and had misperception of teachers' role in ESA classes, more than $50 \%$ of them ( with mean value of 4.40) certified that they have a high positive apprehension of the role of teachers in ESA classes. 
TABLE 5.

PERSPECTIVE ON LEARNERS' ROLE

\begin{tabular}{|c|c|c|c|c|c|c|c|c|c|c|c|c|}
\hline \multirow[t]{2}{*}{ No } & \multirow[t]{2}{*}{ Items } & \multicolumn{2}{|l|}{5} & \multicolumn{2}{|l|}{4} & \multicolumn{2}{|l|}{3} & \multicolumn{2}{|l|}{2} & \multicolumn{2}{|l|}{1} & \multirow[t]{2}{*}{ Mean } \\
\hline & & $\mathrm{F}$ & $\%$ & $\mathrm{f}$ & $\%$ & $\mathrm{f}$ & $\%$ & $\mathrm{f}$ & $\%$ & $\mathrm{~F}$ & $\%$ & \\
\hline 20 . & $\begin{array}{l}\text { Students can suggest what the content of the lesson should be } \\
\text { or what activities are useful for him or her in language } \\
\text { classroom. }\end{array}$ & 5 & 50 & 3 & 30 & 2 & 20 & & & & & 4.30 \\
\hline 21. & $\begin{array}{l}\text { Learners should interact primarily with each other rather than } \\
\text { with the teacher in EFL classroom. }\end{array}$ & 4 & 40 & 3 & 30 & 3 & 30 & & & & & 4.10 \\
\hline $\begin{array}{l}\text { Total } \\
\text { mean }\end{array}$ & & & & & & & & & & & & 4.20 \\
\hline
\end{tabular}

This section of teachers' perception of ESA approach pays attention to perspective of learners' role. Item 20 of the above table indicates that half of the teachers $(50 \%)$ strongly agree on the fact that students can decide on selecting the content of the activities. Taking this principle into consideration, it is made clear that determining the content of the activities, tasks or topics is largely dependent upon students need and interest. Focusing on item 21, 4 and 3 of the teachers strongly agreed and agreed on learners' interaction with their peers rather than with the teacher, though $30 \%$ of them were undecided about learner interaction role.

In conclusion, in ESA approach learners role should not be taken for granted. Since learners play a major role in active learning, their contribution to class discussion, task completion and engagement is a must. Hence wise, attracting leaners attention requires a great deal of energy by the side of the teachers. Therefore, in ESA approach there must be a comprehensive lesson plan specially planned and designed to engage students in class activities and discussions. Additionally, it can be put forward that these activities, class discussion, topic and content of the lesson should be approached according to learners need and interest.

TABLE 6.

PERSPECTIVE ON ESA TEACHER's CLASSROOM PRACTICE

\begin{tabular}{|c|c|c|c|c|c|c|c|c|c|c|c|c|}
\hline \multirow[t]{2}{*}{ No } & \multirow{2}{*}{ Items } & \multicolumn{2}{|l|}{5} & \multicolumn{2}{|l|}{4} & \multicolumn{2}{|l|}{3} & \multicolumn{2}{|l|}{2} & \multicolumn{2}{|l|}{1} & \multirow{2}{*}{ Mean } \\
\hline & & $\mathrm{f}$ & $\%$ & $\mathrm{f}$ & $\%$ & $\mathrm{~F}$ & $\%$ & $\mathrm{~F}$ & $\%$ & $\mathrm{~F}$ & $\%$ & \\
\hline 22. & $\begin{array}{l}\text { ESA teachers" should explain new grammatical terminologies } \\
\text { or forms and patterns (rules) and let the learners be engaged in } \\
\text { doing exercises. }\end{array}$ & 3 & 30 & 4 & 40 & 2 & 20 & 1 & 10 & - & - & 3.90 \\
\hline 23. & $\begin{array}{l}\text { ESA teachers" should explain new words and phrases and let } \\
\text { the learners do the exercises in the textbook. }\end{array}$ & 4 & 40 & 4 & 40 & 1 & 10 & 1 & 10 & - & & 4.10 \\
\hline 24. & Use teacher led - classroom discussion. & 5 & 50 & 4 & 40 & 1 & 10 & & - & - & - & 4.40 \\
\hline 25. & $\begin{array}{l}\text { Give students explanation of rules with model sentences to } \\
\text { illustrate them. }\end{array}$ & 3 & 30 & 3 & 30 & 3 & 30 & 1 & 10 & - & - & 3.80 \\
\hline 26. & Involve students in questioning and answering activities. & 8 & 80 & 2 & 20 & - & - & & - & - & - & 4.80 \\
\hline 27. & Involve learners in role play, simulation or any kind of drama. & 7 & 70 & 3 & 30 & - & - & & - & - & - & 4.70 \\
\hline 28. & Involve learners in problem- solving activities. & 9 & 90 & 1 & 10 & - & - & & - & - & - & 4.90 \\
\hline 29. & $\begin{array}{l}\text { Involve learners in activities as identifying similarities and } \\
\text { differences of pictures in group. }\end{array}$ & 8 & 80 & 2 & 20 & - & - & & - & - & - & 4.80 \\
\hline 30. & Use different kinds of language games e.g. word dominoes. & 1 & 10 & 3 & 30 & 3 & 30 & 3 & 30 & - & - & 3.20 \\
\hline 31. & $\begin{array}{l}\text { Make the learners exchange letters, write reports, } \\
\text { Advertisements etc. cooperatively. }\end{array}$ & 2 & 20 & 3 & 30 & 3 & 30 & 2 & 20 & - & - & 3.20 \\
\hline 32. & Use audiovisual materials to support your lesson. & 3 & 30 & 2 & 20 & 4 & 40 & 1 & 10 & - & - & 3.70 \\
\hline 33. & Use pair work in which two students work on a given task. & 9 & 90 & 1 & 10 & - & - & & - & - & - & 4.90 \\
\hline 34. & $\begin{array}{l}\text { Use group work in which more than two students work on a } \\
\text { given task. }\end{array}$ & 9 & 90 & 1 & 10 & - & - & & - & - & - & 4.90 \\
\hline 35. & $\begin{array}{l}\text { Help learners correct their error in their pair and group } \\
\text { discussion. }\end{array}$ & 6 & 60 & 3 & 30 & 1 & 10 & & - & - & - & 4.50 \\
\hline 36. & $\begin{array}{l}\text { Let learners do assignments at home and give feedback on } \\
\text { other days for the whole class. }\end{array}$ & 4 & 40 & 3 & 30 & 3 & 30 & & - & - & - & 4.10 \\
\hline 37. & $\begin{array}{l}\text { Correct learners" error in controlled practice activities like } \\
\text { question and answer. }\end{array}$ & 3 & 30 & 2 & 20 & 3 & 30 & 2 & 20 & - & - & 3.60 \\
\hline $\begin{array}{l}\text { Total } \\
\text { Mean }\end{array}$ & & & & & & & & & & & & 4.21 \\
\hline
\end{tabular}

This section of the questionnaire focuses on teachers' perspective on classroom practice. Item 22 of this table shows that $30 \%$ of the teachers believe that ESA teachers' should always explain new grammatical terminologies or forms and patterns (rules) and let the learners be engaged in doing exercises. About $40 \%, 20 \%$ and $10 \%$ percent of the respondents said often, sometimes and rarely respectively. Findings of item 22 imply that most of the teachers employ traditional teaching of grammar in their classes.

Similarly in item 23, significant proportions of the teachers frequently explain new words and phrases and let the learners do the exercises in the textbook. And about $10 \%$ of them rarely employs doing it. Based on the mean value of the responses (4.10), it can be concluded that nearly a great proportion of teachers employ non-communicative way of teaching vocabulary. 
The data analysis for item 24, show that teachers always (50\%) and often (40\%) employ teacher- led classroom debates. On the other hand, only 10 percent of the respondents consented that they sometimes use teacher-led discussions. Focusing on item 25, 30\% of teachers 'always', 'often' and 'sometimes' use rules with model sentences to illustrate the lesson. Noticeably, regarding item 26 about student involvement, it is made clear that teachers give a predominant attention to student engagement. $80 \%$ and $20 \%$ of teachers asserted that they always and often employ questioning and answering activities.

Data analysis concerning item 27, 28 and 29 about involving learners in activities like role plays, simulations, problem-solving and picture description activities involve teachers frequent attention to student involvement by the use of different activities. The mean value of 4.70, 4.90 and 4.90 is strong evidence regarding this claim.

As to item 30 about language games, $30 \%$ of teachers asserted that they often, sometimes and rarely use language games in their classes. And only $10 \%$ claimed always using language games like dominoes. This might probably imply that language games take too much time and waste most of the class time.

The mean value 3.20 of item 31 denotes that teachers sometimes prefer to make the learners exchange letters, write reports, advertisements etc. cooperatively. Item 32 of this section about using audiovisual materials to support the lesson indicates that $40 \%$ of the teachers sometimes use audiovisuals to support their lesson. However, $30 \%, 30 \%$ and $10 \%$ claimed that they always, sometimes and rarely use using audiovisual materials to support their lesson. The mean value of 3.70 indicates that most teachers sometimes prefer to use picture and sound materials and most of the time they stick to textbook and their lesson plan.

Pair work and group work activities are the indispensable part of any teaching methodology, since they provide effective feedback as to how much learners have understood the materials taught. Likewise, ESA approach pays a great deal of attention to pair and group work activities. Consequently, most of the teachers with a mean value of 4.90 testify using it.

Most of the teachers $(60 \%)$ mentioned that they always help learners correct their mistakes in pairs or group work activities. $30 \%$ and $10 \%$ asserted they use often and sometimes help learners correct their mistakes in pairs or group work activities respectively (item 35).

Considering item 36, the mean value of 4.10 signify the fact that over $50 \%$ of the teachers let students do assignments at home and give feedback on other days for the whole class. And finally teachers' responses on classroom practice regarding item 37 indicate that only 30 percent show their frequent preference in correcting learners' error in controlled practice activities like question and answer. Respectively, 20\%, 30\% and 20\% of the teachers claim practicing this activity often, sometimes and rarely.

To sum up, the findings of the teachers' responses to classroom practice convey the fact that most teachers prefer ESA approach in teaching activities. However, an average proportion of them prefer traditional way of teaching grammar. They also tend to favor involving students in task activity types. As it could be seen, regarding the three elements of Engagement, Study and activate, teachers choose different styles of teaching these elements.

Ultimately, as the concluding remark of the whole sections, it can arguably be asserted that teachers hold a positive perception of ESA elements in mastering speaking ability of EFL learners. The total mean value of 4.07 is a strong proof to the abovementioned claim.

\section{DISCUSSIONS}

Making recourse to the research question posed earlier, the study sought to explore EFL teachers' perceptions of ESA approach. Accordingly, teachers were asked to observe the experimental class which the treatment was being applied. In this process, they were required to fill in an observation checklist. Then, after the instruction at the end of the course, they were given a questionnaire based on the observation checklist to see their perception of using this method. After data collection, the data were analyzed by using a descriptive method. The mean and frequency of the answers were utilized to differentiate their perception. The questionnaire was analyzed in seven sections. The findings of each section of the questionnaire brought about different perspectives of the teachers' understanding of an ESA use of tasks. Considerably, it was made clear that teachers, regardless of their teaching experiences, convey a significant amount of practical understanding about the key concepts of ESA approach involved in teaching of tasks in promoting EFL learners speaking ability.

In probing the teachers' perception of task-based language teaching the study whose results parallel the findings of this study, Víctor Pavón Vázquez Marta Prieto MolinaFco and Javier Ávila López (2014) investigated the perceptions that teachers and students have of the use of task-based learning as an instrument to favor participation and interaction in CLIL. The results of this study support the optimism for the adoption of task-based learning. They found out that task-based learning contributes to the creation of a cooperative and relaxed learning atmosphere, since students enjoy working with and learning new things in class.

They also found out that teachers make use of appropriate techniques and strategies to promote the use of the foreign language, whether individually or in groups. Teachers' own perception of their work is an important factor in the success of CLIL, as teachers are responsible for providing adequate support by scaffolding students' negotiation of meaning. 


\section{CONCLUSIONS}

The principal purpose of the study was to put attempts into investigating teachers' perception toward the application of ESA elements in mastering speaking ability of Iranian EFL learners. Hence wise, in order to analyze the data descriptive survey method was employed. To meet this objective, questionnaire and classroom observation were utilized as instruments of data collection. The obtained data were analyzed by employing statistical tools such as frequency, percentage and mean using SPSS software. The total mean value of 4.07 is strong evidence that the said null hypothesis was rejected all. However, teachers had different perspectives toward the application of the practical principles of ESA. Consequently, it can rightly be asserted that teachers do have a positive perception of toward the application of ESA elements in promoting EFL learners speaking abilities.

Considerably, it is hoped that findings of the present study would make a specifically significant contribution to the better current situation in teaching and learning speaking English intermediate EFL learners and to the ongoing process of renovation for teaching English. Additionally, it is also expected to find its place in educational syllabus of the English department. Similarly, teachers are recommended to incorporate the instructional procedures deployed in the study.

The present research, although limited in scope, is specifically carried out to develop teachers' apprehension of employing ESA technique involved in teaching of tasks in promoting EFL learners speaking proficiency. On that account, the findings of the study would offer considerable amount of courses of action and implications sine qua non for EFL teachers, EFL learners, syllabus designers, supervisors, material producers, tex tbook writers and researchers.

\section{ACKNOWLEDGMENTS}

First, the present study is fully indebted to Chabahar Maritime University, language department for their invaluable support and guidance in carrying out the present study. Secondly, the researchers would like to express their sincere gratitude and appreciation to the teachers who participated as the subjects of this study.

\section{REFERENCES}

[1] Aardema, Thomas P. (2013). "Student Engagement in LDS Seminaries". All Graduate Theses and Dissertations. Retrieved on 08 Dec 2014 from http://digitalcommons.usu.edu/etd/1464.

[2] Beyene Gebru (2008). "Perception and Classroom Practice of Communicative Language Teaching by High School EFL teachers and Learners: The case of some Selected High Schools in Addis Ababa." (Unpublished M.A Thesis). Addis Ababa: Addis Ababa University.

[3] 3Bygate, M. (1987). Speaking. Oxford: Oxford University Press.

[4] 4Candlin, C.N. (1987). Towards task-based language learning. In C.N. Candlin and D. Murphy (Eds) Lancaster Practical Papers in English Language Education, Vol. 7. Englewood Cliffs, NJ: Prentice Hall

[5] Clarke, M.A. and Silberstein, S. (1977). Toward a realization of psycholinguistic principles in the ESL reading class. Language Learning, 27, 1, 48-65.

[6] Dornyei, Z (2001). Motivational Strategies in the Language Classroom. Cambridge: Cambridge University Press.

[7] Edwards, C \&. Willis, J. (2005). Teachers Exploring Tasks in English Language Teaching. Houndmills, Basingstoke, Hampshire RG21 6XS and 175 Fifth Avenue, New York, N.Y. 10010: PALGRAVE MACMILLAN.

[8] Ellis, R. (2000). 'Task-based research and language pedagogy' Language Teaching Research 4(3): 193-220.

[9] Ellis, R. (2005). Instructed second language acquisition: A literature review. Wellington, New Zealand: Ministry of Education.

[10] Harmer, J. (2001). The Practice of English Language Teaching. Edinburgh: Pearson Education limited.

[11] Harmer, J. (2007). The changing world of English. In The practice of English language teaching. Cambridge: UK, Pearson Longman.

[12] Hover, D. (1986). Think twice: Teacher's book. Cambridge: Cambridge University Press.

[13] Long, M. (1989). 'Task, group, and task-group interaction' University of Hawaii Working Papers in English as a Second Language 8(2): 1-26.

[14] Newmann, F. M., Wehlage, G. G., \& Lamborn, S. D. (1999). The significance and sources of student engagement. In F. M. Newmann \& F. M. Newmann (Eds.), Student engagement and achievement in American secondary schools (pp. 11-39). New York, NY: Teachers College Press. 1234 Amsterdam Avenue, New York, NY 10027 (paperback: ISBN-0-8077-3182-X, \$17.95; hardcover: ISBN-0-8077-3183-8, \$38).

[15] Nunan, D. (1987). Communicative language teaching: making it work. ELT Journal 41. 136-145.

[16] Nunan, D. (1989). Designing Tasks for the Communicative Classroom. New York: Cambridge University Press.

[17] Pica, T., Kanagy, R., \& Falodun, J. (1993). Choosing and using communication tasks for second language instruction. In G. Crookes and S. Gass (Eds.), Tasks and language learning (pp. 9-34). Clevedon, England: Multilingual Matters.

[18] Prince, M. (2004). Does active learning work? A review of the research. Journal of Engineering Education, Washington. 93, 223-232.

[19] Richards, J. C., \& Renandya, W. A. (2002). Methodology in language teaching: An anthology of current practice. Cambridge: Cambridge university press.

[20] Rivers, W. M. (1981). Teaching foreign-language skills. Chicago: University of Chicago Press, 5801 S. Ellis Ave., Chicago, IL 60637.

[21] Silva, A. L. K. D. (2012). The use of Cambridge ESOL parameters in oral performance assessment in an English language institute (Master's thesis). Instituto De Letras: Universidade Federal Do Rio Grande Do Sul. Retrieved 20 March 2014 from: https://www.lume.ufrgs.br/bitstream/handle/10183/70663/000877129.pdf?sequence=1. 
[22] Sinclair, J. and Brazil, D. (1982). Teacher Talk. Oxford: Oxford University Press.

[23] Sinclair, J. and Coulthard, R.M. (1975). Towards an Analysis of Discourse, Oxford: Oxford University. Press.

[24] Shavelson, R.J. and P. Stern (1981). Research on teachers' pedagogical thoughts, judgements, decisions, and behavior. Review of Educational Research 51, 455-498.

[25] Shulman, L. (2002). Making differences: A table of learning. Change, 34(6), 36-44.

[26] Timothy T. Diemer, Eugenia Fernandez, Jefferson W. Streepey. (2012). Student Perceptions of Classroom Engagement and Learning using iPads. Journal of Teaching and Learning with Technology, Vol. 1, No. 2, December 2012. pp. 13 - 25.

[27] Thornbury, S. (1996). Teachers research teacher talk. ELT Journal, 50(4), 279-289.

[28] Thornbury, S. (2005). How to teach speaking. Harlow: Longman.

[29] Torky, S. A. E. (2006). The Effectiveness of a Task-Based Instruction Program in Developing the English Language Speaking Skills of Secondary Stage Students. (Doctoral Dissertation). Retrieved on 24 July 2013 from: http://files.eric.ed.gov/fulltext/ED523922.pdf.

[30] Trappes-Lomax, H. R., \& Ferguson, G. (Eds.). (2002). Language in language teacher education. The Hague: John Benjamins. ISBN: 9027216983.

[31] Ur, P. (1991). A course in Language Teaching. Cambridge: Cambridge University Press.

[32] Vázquez, V. P., Molina, M. P., \& López, F. J. A. (2015). Perceptions of teachers and students of the promotion of interaction through task-based activities in CLIL. Porta Linguarum: revista internacional de didáctica de las lenguas extranjeras, (23), $75-91$.

[33] Williams, J. D.; Friesen, S.; \& Milton, P. (2009). What Did You Do In School Today? Transforming Classrooms through Social, Academic and Intellectual Engagement. (First National Report). Canadian Education Association. Retrieved on 18 December 2013 from: http://www.cea-ace.ca/sites/cea-ace.ca/files/cea-2009-wdydist.pdf.

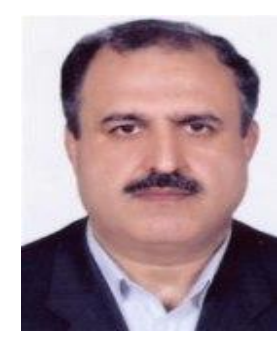

Hooshang Khoshsima is the associate professor of Chabahar Maritime University. He Holds Ph.D. degree in TEFL studies. $\mathrm{He}$ is currently teaching English language courses for $\mathrm{PhD}$ candidates, graduate and undergraduate students in Chabahar Maritime University, English department. He has also written books and articles on different research topics. His main areas of interest include Task-based language teaching (TBLT), computer assisted language learning (CALL), English for specific course (ESP), alternative assessment and teaching skills.

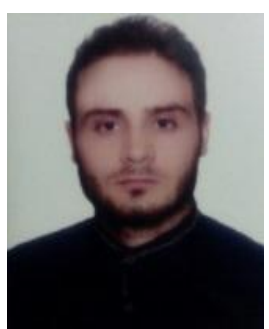

Hadi Shokri holds MA in TEFL in Chabahar Maritime University. He has been teaching language skills in Tehran language schools. He has also written papers on different research topics. His main areas of interest include task-based language teaching (TBLT), teaching skills, speaking, student engagement and motivation. 